\title{
A Training Based on Experiential Learning to Create the Entrepreneur-Characterized Youth
}

\author{
Eko Wanidison ${ }^{1}$, Ihat Hatimah ${ }^{2}$, Joni Rahmat Pramudia ${ }^{3}$ \\ 1,2,3 Public Education Department, Graduate School, Universitas Pendidikan Indonesia, Indonesia \\ eko.wanidison@gmail.com
}

\begin{abstract}
A large number of entrepreneurs who grow in society can be an influencer of the progress of the economy of a nation. This is because the increase of entrepreneurs can lead poverty and unemployment to be minimized. To reach this stage, training is needed to improve the ability of the society to be more creative and innovative. This is as the objectives implemented in the Young Entrepreneur Academy (YEA) to create training programs that focus on creating entrepreneurs. The purpose of this study was to find out the success of YEA in creating prospective entrepreneurs. Furthermore, a descriptive qualitative approach was applied in this study, while, the data in this study were collected through interviews, observation, and documentation. The researchers found that the YEA has various planning programs with a vision to create prospective entrepreneurs who are adapted to the development of the business world. Thus, the YEA is more focused on carrying out training in practice than just a theory. The conclusion is the YEA makes the Experiential Learning program not to create prospective job seekers but aims at creating the candidates for opening jobs.
\end{abstract}

Keywords : training; experiential learning; young entrepreneurs; entrepreneurial character

\section{Introduction}

The current development and the increasing community needs often shake the nation's economic system. Based on this, to balance the economy flow it needs creative effort from the community to be able to become a pioneer in the world of entrepreneurship. Because creative efforts born from the community are believed can reduce poverty. And moreover, many entrepreneurs among the society and state are believed to be able to overcome poverty (Asyarie: 2016). Therefore, through Experiential Learning entrepreneurship training implemented by an institution called Young Entrepreneur Academy (YEA), it is believed can be one of the right solutions in overcoming the problems of poverty and unemployment.

Viewed from what happens in poverty that occurs in this nation, the problem of poverty has highly become one of the government's priorities. Therefore, the government always strives for entrepreneurship training programs because at least $2 \%$ of the population of a country must become an entrepreneur if the country to make a country developed and prosperous (McCleland: 1961). It is undeniable that not only government programs that must be emphasized, but also several private institutions must support the activities of the entrepreneur.

The YEA has a program design to produce prospective creative entrepreneurs because many prospective entrepreneurs often consider a particular business not very attractive, but in fact, it is interesting and has economic value for himself, family and even society (Fadiati \& Purwana: 2011). Because through creativity, it will encourage the entrepreneurship establishment and development in people's lives and certainly will be one solution to overcome poverty (Asyarie: 2016). That is a point that the YEA wants to achieve in running its programs through Experiential Learning. 
The need for informal and non-formal education services is certainly very necessary in supporting a better life for the present and the future (Kamil: 2009). Based on this, the YEA is one of the non-formal private institutions and has a prominent role in training the society to be more creative and innovative. Therefore, YEA as a private institution has a significant role in creating creative entrepreneurs for the sake of fulfilling the balance between prospective workers and the number of jobs.

The YEA is one of the institutions recognizing that basically, the problem of unemployment that occurs in the younger generation is mostly due to low creativity. It is generally known that the ability to be more creative certainly does not just come from prospective entrepreneurs. Therefore, it needs course training and capacity building for them. This is the foundation of the Young Entrepreneur Academy be an alternative way to educate young people to be more competent in understanding the entrepreneurship world. Accordingly, every entrepreneurial institution must provide a method to motivate, provide opportunities and facilitate young entrepreneurs through an organization to create creative and reliable young people (Alma: 2009).

The progress of the YEA trying to create young entrepreneurs is the main goal. This system suggests that titles and educational certificates are not prioritized because after completing the training the young generation must be able to create jobs, not to apply for jobs. The learning system in the YEA is based on Experiential Learning with direct training and even if there is learning theoretically only used as material understanding. Some of the program findings are the basis for researchers researching in YEA. The researcher wants to explore data related to the success of YEA in creating prospective entrepreneurs who are successful in their fields.

\section{Research Methodology}

Data collection used by researchers was a qualitative descriptive research method which is reinforced by Craswell's (2014) statement that "Qualitative research is described comparatively based on theory and application". So, in this case, the researcher tried to understand and explain the data found on the field that were certainly strengthened by several related theories. It means not only understand but also understand more deeply to the core of the phenomenon under study, so understanding data becomes the goal of qualitative research (Herdiansyah, 2012). Therefore, data explored at the YEA was not only limited to understanding its programs, but also the extent of YEA's success in creating prospective entrepreneurs.

The researcher collected data using a descriptive approach with different informants based on the level of education. The interview process was conducted to find out the extent of the success of the YEA and what programs implemented by the YEA to create creative prospective entrepreneurs. The core informants in this study consisted of training participants, alumni, and organizers of training. Through this research, researchers could explain how the success of YEA in overcoming the problem of unemployment and the extent to which entrepreneurial training programs based on experiential learning that are useful to shape the youth having entrepreneurs character. 


\section{Findings and Discussion}

\subsection{Findings}

Based on the results of research conducted in YEA institution, it obtained several findings. Some of which explained that YEA has the vision to be a bridge to prosperity for the Indonesian people by creating reliable and integrity entrepreneurs. Besides, it is also to run creative and innovative entrepreneurial programs. The YEA implements a mission to shift the paradigm of the younger generation of job seekers into job creation mentality, make a fun and practical entrepreneurship training, help to change student behavior having a loser pattern to have a winning pattern, and instill "momentum" values in participants.

The YEA training institution in its planning process conducted needs identifying wherein the process of needs identifying, it conducted a written test regarding DISC personality (Dominance, Influence, Steadiness, Conscientiousness) and a test on entrepreneurial knowledge called the Basic Entrepreneur Diagnostic test. Additionally, all trainees must meet the requirements such as among aged 17-25 years, not being educated, single (unmarried), and pass the written personality test and entrepreneurial knowledge test. In the learning process, something becoming a benchmark for the training organizers when delivering each material in the form of the curriculum was prepared in such a way and conduct briefings in advance with the Team when the new batch would start each stage of the training.

The stages of the training process in YEA were adjusted based on all projects systematically arranged.

Figure 1. Training Phases

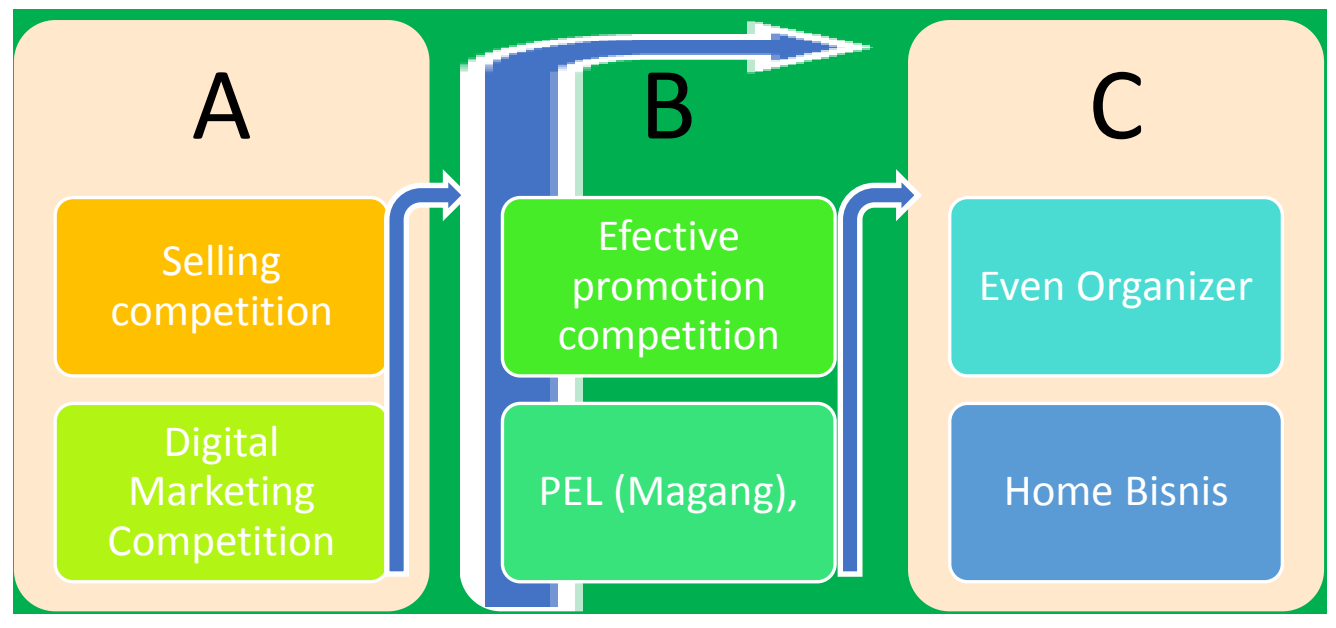

Source: Young Entrepreneur Academy (2009)

The presentation of material as described in the picture above serves to support projects in YEA. For instance, selling competition material teaches basic skills needed for sales ranging from selling skills, negotiation skills, communication skills; basic etiquette summarizes how to meet the right people, how to dress, how to greet people, how to shake hands, and how to eat in front of the client.

Different from selling competition, in the Digital Marketing stage, the trainees will be taught the basic ways to use internet marketing, to advertise, how to make the right way of copywriting, Facebook ads, Instagram ads, then the trainees will directly practice selling 
products via online. additionally, there is an effective promotion in which the client will be given a solution to the business activities undertaken by the trainees. At the project's effective promotion stage, participants will be taught various ways of analyzing, starting from how to increase profits, and how to conduct a swot analysis, problem-solving, and creative thinking. In the next stage, the trainees will have an internship program which functions to train attitudes in people's sites, to make an internship report, and also to analyze based on four business sectors including sales and marketing, operation, finance, and Human Resource.

In the next stage, the trainees will attend an event organizer (EO) program that is taught directly by management. After that, they will practice for further negotiations with sponsors, learn to make event proposals and manage an event. In the final stage, the trainees will take part in-home business activities based on several categories such as business models, design thinking and customer journeys that all of which essentially teach how to understand customer willingness so that trainees can fulfill requests according to customer desires.

In the training method, the YEA institute determines the material made by YEA itself and according to the values available consisted of $70 \%$ of practice and $30 \%$ of theory. Thus, in the training process, more training methods are applied directly than theory. All the training is based on experience which is adjusted to the stages described earlier.

The aim of trainees participating in training activities is generally to become entrepreneurs. Learning resources provided to trainees from the organizers are in the form of soft files that will be shared via trainees' e-mails. Then, trainees will get reading books recommended by the training organizers as learning material for the trainees. The majority of the training time is held from Monday to Friday from $09.00 \mathrm{am}-05.00 \mathrm{pm}$.

In the final stage, there will be evaluation activities carried out at the end of each training activity. At this stage, there will be a score or value given by the facilitator in which the total points are summed. Therefore, the total score will determine the rank obtained by the trainees. The technique used is to fill out the evaluation form provided by the facilitator for the trainees. After that, an evaluation will be given to the organizer and the next facilitator.

\subsection{Discussion}

Sudjana (2010) explained that "identification of learning needs is the activity of looking for, finding out, recording and processing based on the learning need desired or expected by the trainees or the organization". In line with the program implemented by the YEA in carrying out its vision that in carrying out training programs each trainee will get a test that is compatible with their talents and interests. So, in running the followed program, the trainees in YEA do not get a serious problem.

The implementation of a training program is a process of learning activities to achieve the planned goals. The implementation can be in the form of each person's effort in such a way so that they desire and try to achieve the goals that have been planned (Terry: 1993). With the implementation of the common goal, the trainees and YEA Institute will be easier to achieve progress until the vision to reduce poverty and unemployment will be achieved.

As the experiential learning program developing in YEA, it is certainly not as easy as thought in the learning process. Trainees are required to take training seriously based on their interests and talents in the business world. As part of the YEA training, each trainee will get skills, increase interest in learning to be more creative in starting the business world. This is certainly in agreement with Hoover's (Gentry, 1990) opinion that through experiential learning, each trainee will learn to be personally responsible and more affective. All of the changes will 
be seen from the process of behavior, knowledge, skills, or attitudes that are characterized by high levels of trainees' active involvement in learning.

YEA as one of the non-formal institutions hopes that the training participants after graduating can build a business. The business is certainly not far from what they obtained when they attended training based on their talents. As alumni of the YEA, they must practice what has been obtained from the learning process in YEA. So the goal initiated by YEA in creating prospective young entrepreneurs can be achieved and carried out successfully. Kolb (1984) also explained that experiential learning is built based on the idea that experience plays an important role in the learning process both in starting the business and other fields.

As the method applied in training using experiential learning with a composition of $70 \%$ practice and $30 \%$ theory, so training is applied to prioritize direct practice. Each trainee will start the business world fundamentally. The learning theoretically is only delivered in some initial meetings as an introduction. Furthermore, YEA will prioritize practices directly in the entrepreneurial world.

Through entrepreneurship training as applied by YEA, it is believed that everyone will get greater results. That is the basis of the many trainees in YEA interested in participating in the training. Because they think that to be successful people don't have to be from a university or formal education. Thus, by looking at business opportunities, the trainees believe they will be able to compete with other entrepreneurs. This is as explained by Hendro (2011) that the basis of entrepreneurship is creating added value in the market through the process of combining resources with new and different ways to be able to compete in the business world.

Jarvis (1998) also explained that learning experiences such as the learning process to reach knowledge, skills, attitudes, values, and beliefs are the basis to achieve prospective successful entrepreneurs. This is YEA's belief in carrying out the training. It is believed that by giving serious training to trainees, every trainee will be able to become a young entrepreneur because each training program has a goal as a reference to achieve the success of the program.

The learning resources used by YEA Training Institute to facilitate students in achieving learning goals can be in the form of soft files of presentation material, pdf, and others. Through this learning media, each trainee at YEA will feel easier to understand the lesson. YEA also provides reading books recommended by the organizer as learning resources for trainees. From the books, the trainees are facilitated to master the lesson and ready to practice. This is certainly in agreement with the statement of the Association of Educational Communication and Technology AECT (in As'ari: 2007) that learning from various sources in the form of data, people or certain forms that can be used by students both separately and in combination can facilitate students in achieving learning goals.

\section{Conclusion}

Entrepreneurship-based training programs held by YEA consist of several aspects called program planning, implementation, and evaluation. The planning program of entrepreneurship training will be adapted to the needs of the trainees. The needs can be seen by doing DISC (Dominance, Influence, Steadiness, Conscientiousness) personality test and the Basic entrepreneur Diagnostic Test test as the entrepreneurial knowledge test. The material presented is sourced from the existing curriculum in the institution, namely Selling competition, Digital Marketing Competition, Effective promotion competition, Field Entrepreneurship Practices, 
Event Organizer, and Homebis. The training process is more applied to experience-based training methods. Thus, all experiential learning programs have facilitated some young people to be successful entrepreneurs.

\section{References}

Alma, B. (2000). Kewirausahaan. Bandung: Alfabeta.

Astamoen. 2008. Entrepreneurship dalam perspektif kondisi bangsa Indonesia. Bandung: Alfabeta.

Asy'ari M.2016. Filsafat kewirausahaan dan implementasinya. Yogyakarta : LESFI.

Boggs, J.G., Mickel, A.E., and Holtom, B.C. 2007. Experiential learning through interactive drama: An alternative to student role plays. Journal of Management Education 31: 832858.

Creswell, J.W (2012). Research design pendekatan kualitatif, kuantitatif, dan mixed. Yogyakarta: Pustaka Belajar

Drucker,P,F (1994) Innovation and entrepreneurship: Practice and principles. Jakarta: Gelora Aksara Pratama Erlangga.

Fadiati,A , Purwana,D (2011) Menjadi wirausaha sukses. Bandung: PT.Remaja Rosdakarya.

Kamil,M (2010) Model pendidikan dan pelatihan, konsep dan aplikasi. Bandung: Alfabeta.

Kolb, D.A. 1984. Experiential pearning. Prentice-Hall Inc., New Jersey.

Moekijat (1993). Evaluasi pelatihan dalam rangka peningkatan produktifitas perusahaan. Bandung: Mandar Maju.

Sudjana D.2007. Sistem manajemen pelatihan. Bandung: Falah Production.

Sudjana D.2004. Pendidikan nonformal. Bandung: Falah Production. 